\title{
PENGARUH PROFITABILITAS, KEBIJAKAN HUTANG, LIKUIDITAS, DAN KEPEMILIKAN INSTITUSIONAL TERHADAP KEBIJAKAN DIVIDEN
}

\author{
Eri Septika, Rina Mudjiyanti*, Eko Hariyanto, Hardiyanto Wibowo
}

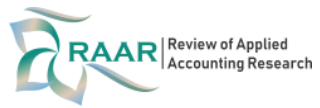

Affiliation:

Accounting Department, Universitas Muhammadiyah

Purwokerto, Indonesia

\section{*Correspondence:}

rinamudjiyantie17@gmail.com

Article Process:

Submitted:

September 12, 2021

Reviewed:

September 20, 2021

Revised:

October 1, 2021

Accepted:

October 9, 2021

Published:

October 10, 2021

\section{Citation:}

Septika, E., Mudjiyanti, R., Hariyanto,E., Wibowo, H. (2021). Pengaruh Profitabilitas, Kebijakan Hutang, Likuiditas, Dan Kepemilikan Institusional Terhadap Kebijakan Dividen. RAAR: Review of Applied Accounting Research, 1(2), 84 93.

\section{Office Address:}

Jl. K.H. Ahmad Dahlan, Dukuhwaluh, Kec.

Kembaran,

Kab.Banyumas, Jawa

Tengah 53182

e-ISSN : 2807-8969

\begin{abstract}
ABSTRAK
Tujuan penelitian ini untuk mengetahui pengaruh profitabilitas, kebijakan hutang, likuiditas, dan Kepemilikan Institusional terhadap kebijakan dividen. Sampel dalam penelitian ini adalah perusahaan Food And Beverage yang terdaftar di Bursa Efek Indonesia Periode (2015-2019). Pemili0068an sampel dalam penelitian ini dilakukan dengan purposive sampling dan didapatkan sebanyak 59 sampel observasi.Teknik analisis data yang digunakan dalam penelitian ini yaitu analisis regresi linear berganda, dan uji hipotesis. Hasil analisis menunjukan bahwa profitabilitas berpengaruh positif terhadap kebijakan dividen, kebijakan hutang berpengaruh positif terhadap kebijakan dividen, likuiditas tidak berpengaruh terhadap kebijakan dividen, dan kepemilikan institusional tidak berpengaruh terhadap kebijakan dividen.
\end{abstract}

Kata Kunci : Kebijakan Dividen, Profitabilitas, Kebijakan Hutang, Likuiditas, Kepemilikan Institusional.

\section{ABSTRACT}

This study aims to determine the effect of profitability, debt policy, liquidity, and institutional ownership on dividend policy. The sample in this study is Food And Beverage companies listed on the Indonesia Stock Exchange Period (2015-2019). The sample selection in this study was carried out by purposive sampling and obtained as many as 59 observation samples. The data analysis techniques used in this study were multiple linear regression analysis and hypothesis testing. The analysis results show that profitability has a positive effect on dividend policy, debt policy has a positive effect on dividend policy, liquidity has no effect on dividend policy, and institutional ownership has no effect on dividend policy.

Keywords: Dividend Policy, Profitability, Debt Policy, Liquidity, Institutional Ownership. 


\section{PENDAHULUAN}

85 Investor menanamkan modal untuk mendapatkan keuntungan dalam bentuk dividen, pembagian dividen yang diinginkan oleh investor adalah dividen yang tinggi dan stabil. Dividen yang dibagikan dalam bentuk tunai lebih diharapkan oleh investor Wuisan dkk (2018). Kebijakan dividen merupakan keputusan yang dibuat oleh perusahaan apakah laba yang diperoleh perusahaan akan dibagikan kepada pemegang saham sebagai dividen atau akan ditahan sebagai bentuk laba ditahan guna untuk pembiayaan investasi di masa yang akan datang Hardi dan Rina (2018). Semakin tinggi profitabilitas pada perusahaan maka akan semakin tinggi tingkat pembagian dividen.

Salah satu faktor yang mempengaruhi kebijakan dividen antara lain adalah profitabilitas Fatmawati (2020). Faktor lain yang mempengaruhi kebijakan dividen yaitu kebijakan hutang Prima dkk (2018). Menurut Prima dkk (2018) Kebijakan hutang berhubungan erat dengan persoalan pembiayaan untuk pelaksanaan perencanaan perusahaan yang akan dikembangkan. Likuiditas merupakan faktor yang memiliki pengaruh terhadap kebijakan dividen Putri dan Andayani (2017).

Perusahaan yang memiliki tingkat likuiditas yang tinggi akan memberikan gambaran bahwa perusahaan mampu memenuhi kewajiban jangka pendeknya Monika dan Luh (2018). Faktor lain yang memiliki pengaruh terhadap kebijakan dividen adalah kepemilikan institusional Novianti dan Lailatul (2017) Kepemilikan institusional adalah kepemilikan saham yang dimiliki oleh pihak eksternal yaitu instansi / lembaga yang dapat meningkatkan pengawasan (Sutanto dkk, 2017).

Industri barang konsumsi merupakan sektor yang memproduksi kebutuhan sehari-hari masyarakat. Food and beverage merupakan salah satu subsektor industri barang konsumsi. Pada saat ini industri barang konsumsi khususnya pada subsektor food and beverage telah mengalami perkembangan yang cukup pesat. Berdasarkan data yang di peroleh dari (Rihanto, 2019) "pada 2018, ekspor industri makanan tumbuh $11,71 \%$ sedangkan minuman tumbuh 3,16\%. Pada tahun 2019, sektor tersebut mampu menarik investasi sebesar US\$383 juta dan Rp8,9 triliun hingga triwulan I Tahun 2019. Dalam hal tenaga kerja, sektor makanan dan minuman juga sudah menyerap 1,2 juta orang di tahun 2018". Hal tersebut menunjukkan bahwa industri barang konsumsi pada subsektor food and beverage merupakan perusahaan yang memiliki prospek yang baik sehingga dapat menarik para investor untuk berinvestasi. Tujuan penelitian untuk menguji pengaruh positif profitabilitas, hutang, likuiditas, kepemilikan institusional terhadap kebijakan dividen.

\section{TINJAUAN PUSTAKA}

\section{Teori Keagenan (Agency Theory)}

Jensen dan Meckling (1976), menyatakan bahwa teori yang mengemukakan mengenai pentingnya pemegang saham sebagai pemilik perusahaan. Keagenan dapat dikatakan seperti kerjasama antara manajer dengan investor. Principal adalah pemegang saham dan agen adalah manajemen yang mengelola perusahaan (Novianti dan Lailatul, 2017); (Azizah dan Nurcahyani, 2020). Principal berharap dividen yang akan dibagikan oleh perusahaan tinggi sedangkan agent berharap dividen yang akan dibagikan kecil, karena agent ingin menahan laba yang akan digunakan untuk membayar hutang atau meningkatkan investasi (Putri, 2017).

\section{Teori Sinyal (Signalling Theory)}

Teori sinyal pertama kali dicetuskan oleh Spence (1933). Teori sinyal melibatkan dua pihak yaitu pihak dalam seperti manajemen dan pihak luar seperti investor yang berperan 
sebagai pihak yang menerima sinyal. Teori sinyal yang dikembangkan oleh Ross (1977) didasarkan atas adanya asymentris information antara pihak manajemen yang memiliki informasi lebih lengkap daripada investor. Kebijakan dividen merupakan sinyal yang dilakukan oleh pihak manajemen kepada investor bahwa badan usaha sedang dalam kondisi baik (Hardi dan Rina, 2018).

\section{Bird-in-Hand Dividend Theory}

Gordon dan Lintner mengemukakan bahwa berdasarkan bird in the hand theory, kebijakan dividen berpengaruh positif terhadap harga pasar saham. Artinya, jika perusahan membagikan dividen dalam jumlah yang besar, maka harga pasar saham perusahaan tersebut akan semakin tinggi dan jika dividen yang dibagikan perusahaan dalam jumlah yang turun, maka harga pasar saham perusahaan akan semakin rendah (Widiyanto dan Anggi, 2018).

\section{METODE PENELITIAN}

Populasi yang terdapat dalam penelitian ini adalah perusahaan Food And Beverage yang terdaftar dalam situs Bursa Efek Indonesia (BEI) yaitu www.idx.co.id. Sedangkan sampel yang dipilih menggunakan teknik purposive sampling yang merupakan teknik pengambilan sampel dengan kriteria tertentu. Adapun kriteria-kriteria tersebut antara lain perusahaan food And beverage yang menerbitkan laporan keuangan tahunan untuk periode terakhir 31 Desember tahun 2015-2019. Perusahaan food And beverage yang memiliki data lengkap terkait variabel-variabel yang digunakan.

\section{Hasil Dan Pembahasan}

Tabel 1. Uji Statistik Deskriptif

Descriptive Statistics

\begin{tabular}{llllll}
\hline & $\mathrm{N}$ & Minumum & Maximum & Mean & Std. Deviation \\
\hline DPR & 59 & 0,080 & 8,530 & 0,69119 & 1,257983 \\
ROA & 59 & 1,320 & 52,670 & 12,51475 & 10,594344 \\
DER & 59 & 13,420 & 183,060 & 82,56508 & 50,988503 \\
CR & 59 & 58,420 & 1582,230 & 300,26678 & 279,020347 \\
KI & 59 & 0,003 & 95,420 & 59,49010 & 24,332588 \\
Valid N (listwise) & 59 & & & & \\
\hline
\end{tabular}

Sumber : Data Diolah, 2020

Analisis deskriptif menjelaskan mengenai gambaran variabel-variabel yang diteliti baik independen maupun dependen dalam periode penelitian. Variabel-variabel yang dimaksud adalah:

1. Kebijakan Dividen

Berdasarkan tabel statistik deskriptif dapat diketahui bahwa pada tahun 2015-2019 nilai rata-rata kebijakan dividen yang diproksikan dengan Dividend Payout Ratio (DPR) sebesar 0,69119 dan standar deviasi sebesar 1,257983 ini menunjukan bahwa variabel kebijakan dividen masing-masing bervariasi 1,26 persen dari rata-ratanya sebesar 0,69 persen. Nilai kebijakan dividen tertinggi sebesar 8,530 dimiliki oleh PT Campina Ice Cream Industry Tbk. pada tahun 2019 dan nilai kebijakan dividen terendah sebesar 0,080 dimiliki oleh Multi Bintang Indonesia Tbk. pada tahun 2019. 
Nilai standar deviasi lebih besar dari nilai mean yaitu $1,257983>0,69119$ menunjukkan bahwa sebaran datanya bersifat heterogen, karena sebaran datanya terlalu luas dimana standar deviasi merupakan pencerminan penyimpangan yang sangat tinggi. Sehingga menunjukan hasil yang tidak normal dan menyebabkan bias.

2. Profitabilitas

Berdasarkan tabel statisik deskriptif dapat diketahui bahwa pada tahun 2015-2019 nilai rata-rata variabel profitabilitas yang diproksikan dengan Return On Assets (ROA) sebesar 12,51475 dan standar deviasi sebesar 10,594344 artinya profitabilitas memiliki sebaran kecil karena standar deviasi lebih kecil dari nilai rata-rata. Nilai rata-rata lebih besar dari standar deviasi ini mengindikasikan bahwa nilai rata-rata dapat digunakan sebagai representasi dari keseluruhan data. Nilai profitabilitas tertinggi sebesar 52,670 dan nilai profitabilitas terendah sebesar 1,320. Nilai tertinggi dari profitabilitas adalah pada Multi Bintang Indonesia Tbk. pada tahun 2017. PT Bank Victoria Syariah pada tahun 2016 dan nilai terendah dari profitabilitas adalah pada PT Budi Starct \& Sweetener Tbk. pada tahun 2016.

3. Kebijakan Hutang

Berdasarkan tabel statistik deskriptif dapat diketahui bahwa pada tahun 2015-2019 nilai rata-rata kebijakan hutang yang diproksikan dengan Debt to Equity Ratio (DER) sebesar 82,56508 dan standar deviasi sebesar 50,988503 artinya kebijakan hutang memiliki sebaran kecil karena standar deviasi lebih kecil dari nilai rata-rata. Nilai ratarata lebih besar dari standar deviasi ini mengindikasikan bahwa nilai rata-rata dapat digunakan sebagai representasi dari keseluruhan data. Nilai kebijakan hutang tertinggi sebesar 183,060 dan nilai kebijakan hutang terendah sebesar 13,420. Nilai tertinggi dari kebijakan hutang adalah pada PT Garudafood Putra Putri Jaya Tbk. pada tahun 2017 dan nilai terendah dari kebijakan hutang adalah pada PT Campina Ice Cream Industry Tbk pada tahun 2018.

4. Likuiditas

Berdasarkan tabel statistik deskriptif dapat diketahui bahwa pada tahun 2015-2019 nilai rata-rata likuiditas yang diproksikan dengan Current Ratio (CR) sebesar 300,26678 dan standar deviasi sebesar 279,020347 artinya likuiditas memiliki sebaran kecil karena standar deviasi lebih kecil dari nilai rata-rata. Nilai rata-rata lebih besar dari standar deviasi ini mengindikasikan bahwa nilai rata-rata dapat digunakan sebagai representasi dari keseluruhan data. Nilai likuiditas tertinggi sebesar 1582,230 dan nilai likuiditas terendah sebesar 58,420. Nilai tertinggi dari kebijakan hutang adalah pada PT Campina Ice Cream Industry Tbk pada tahun 2017 dan nilai terendah dari kebijakan hutang adalah pada Multi Bintang Indonesia Tbk. pada tahun 2015.

5. Kepemilikan Institusional

Berdasarkan tabel statistik deskriptif dapat diketahui bahwa pada tahun 2015-2019 nilai rata-rata kepemilikan institusional yang diproksikan dengan KI sebesar 59,49010 dan

\section{RAAR}

Vol.1 No.2 standar deviasi sebesar 24,332588 artinya kepemilikan institusional memiliki sebaran kecil karena standar deviasi lebih kecil dari nilai rata-rata. Nilai rata-rata lebih besar dari standar deviasi ini mengindikasikan bahwa nilai rata-rata dapat digunakan sebagai representasi dari keseluruhan data. Nilai kepemilikan institusional tertinggi sebesar 95,420 dan nilai kepemilikan institusional terendah sebesar 0,003. Nilai tertinggi dari 
kepemilikan institusional adalah pada PT Sariguna Primatirta Tbk. pada tahun 2016 dan nilai terendah dari kepemilikan institusional adalah pada PT Campina Ice Cream Industry Tbk pada tahun 2017 dan 2018.

\section{Analisis Regresi Linear Berganda}

Tabel 2. Hasil Uji Regresi Linear Berganda

Coefficients $^{\mathrm{a}}$

\begin{tabular}{|c|c|}
\hline $\begin{array}{l}\text { Unstandardized } \\
\text { Coefficients }\end{array}$ & $\begin{array}{l}\text { Standardized } \\
\text { Coefficients }\end{array}$ \\
\hline
\end{tabular}

\section{Std.}

\begin{tabular}{llllll} 
Model & B & Error & Beta & t & Sig. \\
\hline 1 & & & & & \\
(Constant) & $-0,102$ & 0,170 & & $-0,601$ & 0,550 \\
ROA & 0,008 & 0,004 & 0,307 & 2,329 & 0,024 \\
DER & 0,002 & 0,001 & 0,379 & 2,311 & 0,025 \\
CR & 0,000 & 0,000 & 0,302 & 1,851 & 0,070 \\
KI & 0,003 & 0,002 & 0,265 & 1,936 & 0,058 \\
\hline
\end{tabular}

Sumber: Data diolah, 2020

Berdasarkan pada hasil koefisian regresi diatas, maka dapat dibuat model persamaan regresi berganda sebagai berikut:

$$
\mathrm{DPR}=-0,102+0,008 \mathrm{ROA}+0,002 \mathrm{DER}+0,000 \mathrm{CR}+0,003 \mathrm{KI}+\mathrm{e}
$$

\section{Uji Model (Uji F)}

Tabel 3. Hasil Uji F

ANOVA $^{\mathrm{a}}$

\begin{tabular}{|c|c|c|c|c|c|}
\hline Model & $\begin{array}{l}\text { Sum } \\
\text { Squares }\end{array}$ & of & Mean Square & $\mathrm{F}$ & Sig. \\
\hline \multicolumn{6}{|l|}{1} \\
\hline Regression & 1,461 & 4 & 0,365 & 5,507 & $0,001^{\mathrm{b}}$ \\
\hline Residual & 3,448 & 52 & 0,066 & & \\
\hline Total & 4,909 & 56 & & & \\
\hline
\end{tabular}

Sumber: Data diolah, 2020

Dari hasil tabel 3 menunjukan nilai signifikasi 0,001 kurang dari 0,05 yang dapat disimpulkan bahwa model tersebut layak digunakan untuk memprediksi pengaruh profitabilitas, kebijakan hutang, likuiditas dan kepemilikan institusional terhadap kebijakan dividen.

\section{Uji Koefisien Determinasi $\left(\mathbf{R}^{2}\right)$}

Tabel 4. Hasil Uji Koefisien Determinasi $\left(\mathrm{R}^{2}\right)$

Model Summary

\begin{tabular}{|c|c|c|c|c|}
\hline Model & $\mathrm{R}$ & $\begin{array}{l}\mathrm{R} \\
\text { Square }\end{array}$ & $\begin{array}{l}\text { Adjusted } \mathrm{R} \\
\text { Square }\end{array}$ & $\begin{array}{l}\text { Std. Error of the } \\
\text { Estimate }\end{array}$ \\
\hline
\end{tabular}




$$
1 \quad 0,545^{\mathrm{a}} \quad 0,298 \quad 0,244 \quad 0,257508
$$

Sumber: Data diolah, 2020

Berdasarkan tabel 4 yang telah disajikan diatas nilai adjusted $\mathrm{R}^{2}$ sebesar 0,244 atau $24,4 \%$. Hal ini berarti bahwa 24,4\% variabel dependen kebijakan dividen dapat dijelaskan secara signifikan oleh variasi variabel profitabilitas, kebijakan hutang, likuiditas dan kepemilikan institusional, sedangkan sisanya 75,6\% dijelaskan oleh variabel lain diluar model regresi dalam penelitian ini.

\section{Hasil Pengujian Hipotesis Pertama}

Berdasarkan tabel uji t menunjukkan variabel profitabilitas yang diproksikan oleh Return On Assets memiliki sig sebesar 0,024<0,05, nilai thitung 2,329 lebih besar dari tabel atau 2,329 > 1,67412 maka $\mathrm{H}_{\mathrm{o}}$ ditolak dan $\mathrm{H}_{\mathrm{a}}$ diterima, dan koefisien regresi 0,008, artinya profitabilitas berpengaruh positif terhadap kebijakan dividen sehingga $\mathrm{H} 1$ diterima. Hasil penelitian ini menunjukkan bahwa profitabilitas dalam perusahaan memiliki pengaruh yang besar terhadap kebijakan dividen. Hasil penelitian ini selaras dengan penelitian Fatmawati dkk (2020), Yudiana dan I Ketut (2016), Silaban dan Ni Ketut (2016) yang menunjukkan bahwa profitabilitas berpengaruh positif terhadap kebijakan dividen.

\section{Hasil Pengujian Hipotesis Kedua}

Berdasarkan tabel uji t menunjukkan variabel kebijakan hutang yang diproksikan dengan Debt to Equity Ratio memiliki nilai sig sebesar 0,025 < 0,05, nilai $t_{\text {hitung }} 2,311$ lebih besar dari tabel atau 2,311> 1,67412 maka $\mathrm{H}_{\mathrm{o}}$ ditolak dan $\mathrm{H}_{\mathrm{a}}$ diterima, dan koefisien regresi 0,002, artinya kebijakan hutang berpengaruh positif terhadap kebijakan dividen sehingga $\mathrm{H} 2$ diterima. Hasil penelitian ini menunjukkan bahwa kebijakan hutang dalam perusahaan memiliki pengaruh yang besar terhadap kebijakan dividen. Hasil penelitian ini selaras dengan penelitian Hardi dan Rina (2018), Prima dkk (2018), Winna dan Hendang (2019), yang menunjukkan bahwa kebijakan hutang berpengaruh positif terhadap kebijakan dividen.

\section{Hasil Pengujian Hipotesis Ketiga}

Berdasarkan tabel uji t menunjukkan variabel likuiditas yang diproksikan dengan Current ratio memiliki nilai sig sebesar $0,070>0,05$, nilai thitung 1,851 lebih besar dari tabel atau 1,851>1,67412 maka $\mathrm{H}_{\mathrm{o}}$ ditolak dan $\mathrm{H}_{\mathrm{a}}$ diterima, dan koefisien regresi 0,000, artinya likuiditas tidak berpengaruh terhadap kebijakan dividen sehingga H3 ditolak. Hasil penelitian ini menunjukkan bahwa likuiditas tidak berpengaruh terhadap kebijakan dividen. Hal ini sejalan dengan penelitian (Astuti dan I Putu, 2019), Ginting (2018), dan Pangestuti (2019).

\section{Hasil Pengujian Hipotesis Keempat}

Berdasarkan tabel $\mathrm{t}$ menunjukkan variabel kepemilikan institusional yang diproksikan dengan KI memiliki nilai sig sebesar $0,058>0,05$, nilai $t_{\text {hitung }} 1,936$ lebih besar dari $t_{\text {tabel }}$ atau 1,936>1,67412 maka $\mathrm{H}_{\mathrm{o}}$ ditolak dan $\mathrm{H}_{\mathrm{a}}$ diterima, dan koefisien regresi 0,003, artinya kepemilikan institusional tidak berpengaruh terhadap kebijakan dividen sehingga $\mathrm{H} 4$ Hendra, 2017), Sari (2014) dan Kartini (2017). 


\section{Kesimpulan}

Penelitian ini dimaksudkan untuk menguji pengaruh profitabilitas, kebijakan hutang, likuiditas, dan kepemilikan institusional terhadap kebijakan dividen studi empiris pada perusahaan food And beverage yang terdaftar di Bursa Efek Indonesia periode 2015-2019. Simpulan yang dapat diambil dari penelitian ini adalah sebagai berikut profitabilitas, kebijakan hutang berpengaruh positif terhadap kebijakan dividen. Likuiditas dan kepemilikan institusional tidak berpengaruh terhadap kebijakan dividen.

\section{Saran}

Berdasarkan kesimpulan dan keterbatasan yang telah dijelaskan diatas, maka peneliti dapat memberikan saran untuk penelitian selanjunya sebagai berikut, peneliti selanjutnya diharapkan meneliti sektor lain yang memiliki komponen data penelitiannya lebih lengkap dibandingkan dengan perusahaan food and beverage, sehingga tingkat generalisasi hasil penelitian semakin tinggi. Bagi peneliti selanjutnya yang ingin meneliti tentang kebijakan dividen lebih baik menambah atau mengganti variabel independen selain profitabilitas, kebijakan hutang, likuiditas, dan kepemilikan institusional sehingga akan memaksimalkan hasil penelitian mengenai kebijakan dividen.

\section{REFERENSI}

Astuti, N. K. B., \& Yadnya, I. P. (2019). Pengaruh Profitabilitas, Likuiditas, Dan Ukuran Perusahaan Terhadap Nilai Perusahaan Melalui Kebijakan Dividen. E-Jurnal Manajemen, 8(5), 3275-3302.

Azizah, S. N., \& Nurcahyani, Y. (2020). Corporate Governance Index, Corporate Ownership Structure and Audit Committee on Debt Costs. Muhammadiyah Riau Accounting and Business Journal, 1(2), 072-080.

Duli, Nikolaus. 2019. Metode Penelitian Kuantitaif : Beberapa Konsep Dasar untuk Penulisan Skripsi \& Analisis Data dengan SPSS. Yogyakarta: Grup Penerbitan CV BUDI UTAMA.

Fatmawati, I., Arifin, R., \& Slamet, A. R. (2020). Pengaruh Kepemilikan Institusional, Profitabilitas, Kebijakan Hutang Dan Ukuran Perusahaan Terhadap Kebijakan Dividen (Studi Kasus Pada Perusahaan Food And Beverage Periode 20162018). Jurnal Ilmiah Riset Manajemen, 9(09).

Ghozali, Imam. 2016. Aplikasi Analisis Multivariate dengan Program SPSS 23. Semarang: Universitas Diponegoro.

Ginting, S. (2018). Pengaruh Likuiditas, Profitabilitas. Dan Leverage Terhadap Kebijakan Deviden Pada Perusahaan Lq45 Yang Terdaftar Di Bursa Efek Indonesia Periode 2012-2016. Jurnal Wira Ekonomi Mikroskil: JWEM, 8(2), 195-204.

Hanafi, Mamduh M., dan Abdul Halim 2016. Analisis Laporan Akuntansi. Edisi kelima. UUP STIM YKPN.

Hardi, S., \& Andestiana, R. (2019). Pengaruh Profitabilitas, Kebijakan Hutang Dan Pertumbuhan Aset Terhadap Kebijakan Dividen (Pada Perusahaan Food And Beverage Yang Terdaftar Di Bursa Efek Indonesia Periode 2013-2017). Jurnal Dinamika Umt, 2(2), 44-58. 
Horne, James C.Van., dan John M. Wachowicz, JR 2007. Fundamental of Financial Management. Edisi 12 Buku 2. Salemba Empat.

Indriani, W., Susilawati, R. A. E., \& Purwanto, N. (2016). Pengaruh Kepemilikan Manajerial Dan Kinerja Keuangan Terhadap Kebijakan Dividen Pada Perusahaan Manufaktur Yang Terdaftar Di Bursa Efek Indonesia Tahun 2012-2014. Jurnal Riset Mahasiswa Akuntansi, 4(1).

Ismiati, P. I., \& Yuniati, T. (2017). Pengaruh Kepemilikan Manajerial, Kepemilikan Institusional dan Kebijakan Hutang Terhadap Kebijakan Dividen. Jurnal Ilmu dan Riset Manajemen (JIRM), 6(3).

Kariyoto. 2017. Analisis Laporan Keuangan. UB Press, Malang.

Kartini, C. P. (2017). Pengaruh Kebijakan Dividen, Ukuran Perusahaan, Kepemilikan Manajerial, Kepemilikan Institusional, Dan Profitabilitas Terhadap Kebijakan Hutang Pada Perusahaan Manufaktur Yang Terdaftar Di Bursa Efek Indonesia (Doctoral Dissertation, Universitas Stikubank Semarang).

Kieso, Donald E. Weygandt, Jerry J. Kimmel, Paul D. 2007. Pengantar Akuntansi. Salemba Empat, Jakarta.

Lita, Kurniawati. Sahala, Manalu. R.J. Negoro, Octavianus. 2015. Pengaruh Kepemilikan Institusional Terhadap Kebijakan Dividen, dan Harga Saham. Jurnal Manajemen, Vol. 15 (1).

Monika, N. G. A. P. D., \& Sudjarni, L. K. (2018). Pengaruh likuiditas, profitabilitas dan leverage terhadap kebijakan dividen pada perusahaan manufaktur di Bursa Efek Indonesia. E-Jurnal Manajemen Universitas Udayana, 7(2).

Novianti, Z. E. W., \& Amanah, L. (2017). Pengaruh Profitabilitas, Growth, Kebijakan Hutang dan Kepemilikan Institusional Terhadap Kebijakan Dividen. Jurnal Ilmu dan Riset Akuntansi (JIRA), 6(9).

Pangestuti, D. C. (2019). Analisis Faktor-Faktor Yang Mempengaruhi Kebijakan Dividen. Jurnal Mitra Manajemen, 3(11), 1055-1072.

Pramaswari, T. (2018). Pengaruh Kepemilikan Manajerial, Kebijakan Hutang, Dan Kesempatan Investasi Terhadap Kebijakan Dividen (Pada Perusahaan Properti Dan Real Estate Yang Terdaftar Di Bursa Efek Indonesia Tahun 2012-2016).

Prima, N. A., Mardani, R. M., \& ABS, M. K. (2018). Pengaruh Kebijakan Hutang dan Profitabilitas Terhadap Kebijakan Dividen (Study Pada Perusahaan Food and Beverage yang Terdaftar di BEI Tahun 2014-2016). Jurnal Ilmiah Riset Manajemen, 7(6).

Purnawati, N. K., \& Purnawati, N. K. (2016). Pengaruh profitabilitas, struktur kepemilikan, pertumbuhan perusahaan dan efektivitas usaha terhadap kebijakan dividen pada perusahaan manufaktur. E Jurnal Manajemen Unud, 5(2).

RAAR

Vol.1 No.2

Purwanto, S. P. (2019). Pengaruh Kepemilikan Manajerial, Kebijakan Hutang, Likuiditas dan Profitabilitas Terhadap Kebijakan Dividen pada Perusahaan LQ-45 (Doctoral dissertation, STIE Perbanas Surabaya). 
Putri, A. R. (2017). Pengaruh Kebijakan Hutang, Profitabilitas, Likuiditas, Dan Kesempatan Investasi Terhadap Kebijakan Dividen. Jurnal Ilmu dan Riset Akuntansi (JIRA), 6(6).

Rahmawati, Syarifah 2017. Konflik Keagenan dan Tata Kelola Perusahaan di Indonesia. Edisi Pertama. Syiah Kuala University Press.

Rais, B. N., \& Santoso, H. F. (2017). Pengaruh Kepemilikan Manajerial, Kepemilikan Institusional, Profitabilitas dan Ukuran Perusahaan Terhadap Kebijakan Deviden. Ilmiah Manajemen Bisnis.

Sari, E. S. (2014). Pengaruh ukuran perusahaan, likuiditas, profitabilitas, pertumbuhan perusahaan, dan kepemilikan institusional terhadap kebijakan devidend payout ratio (DPR). EKOMBIS REVIEW: Jurnal Ilmiah Ekonomi dan Bisnis, 2(2).

Sari, N. K. A., \& Budiasih, I. G. A. (2016). Pengaruh Kepemilikan Managerial, Kepemilikan Institusional, Free Cash Flow Dan Profitabilitas Pada Kebijakan Dividen. E-Jurnal Akuntansi Universitas Udayana, 15(3), 2439-2466.

Sari, N., Ayu, K., \& Sudjarni, L. K. (2015). Pengaruh likuiditas, leverage, pertumbuhan perusahaan, dan profitabilitas terhadap kebijakan dividen pada perusahaan manufaktur di BEI. E-Jurnal Manajemen Universitas Udayana, 4(10).

Sari, N. P. A. S. P., \& Suryantini, N. P. S. (2019). Pengaruh Profitabilitas, Likuiditas, dan Tingkat Pertumbuhan Terhadap Kebijakan Dividen Pada Perusahaan Manufaktur. E-Jurnal Manajemen, 8(7), 4559-4588.

Subagyo, dkk 2018. Akuntansi Manajemen Berbasis Desain. Gadjah Mada University Press.

Sudana, I.M. 2009. Manajemen Keuangan Teori dan Praktik. Cetakan Pertama. Pusat Penerbitan dan Percetakan Unair (AUP). Surabaya.

Sumanti, J. C., \& Mangantar, M. (2015). Analisis kepemilikan manajerial, kebijakan hutang dan profitabilitas terhadap kebijakan dividen dan nilai perusahaan pada perusahaan manufaktur yang terdaftar di BEI. Jurnal EMBA: Jurnal Riset Ekonomi, Manajemen, Bisnis dan Akuntansi, 3(1).

Sutanto, J., Marciano, D., \& Ernawati, E. (2017). Pengaruh Kepemilikan Institusional Terhadap Kebijakan Dividen Pada Perusahaan Sektor Industri Property, Real Estate, Dan Konstruksi Bangunan Yang Terdaftar Di BEI Periode 20112015. CALYPTRA, 6(2), 966-981.

Taroreh, R., \& Thaib, C. (2015). Pengaruh kebijakan hutang dan profitabilitas terhadap kebijakan dividen (studi pada perusahaan foods and beverages yang terdaftar di bei tahun 2010-2014). Jurnal Riset Ekonomi, Manajemen, Bisnis dan Akuntansi, 3(4), 2816.

Tarmizi, R., \& Agnes, T. (2016). Pengaruh Kepemilikan Manajerial, Kepemilikan Institusional, Free Cash Flow dan Profitabilitas Terhadap Kebijakan Dividen pada Perusahaan Manufaktur Go Public yang Terdaftar Di BEI (Periode 20102013). Jurnal Akuntansi dan Keuangan, 7(1). 
Wijayanto, E., \& Putri, A. N. (2018). Analisis Pengaruh Rasio Likuiditas, Rasio Leverage, Rasio Profitabilitas Dan Kepemilikan Manajerial Terhadap Kebijakan Dividen. Jurnal Aktual Akuntansi Keuangan Bisnis Terapan (AKUNBISNIS), 1(2).

Winna, H. T. (2019). Pengaruh Profitabilitas, Likuiditas Dan Kebijakan Utang Terhadap Kebijakan Dividen Pada Perusahaan Manufaktur. Jurnal Paradigma Akuntansi, 1(2), 523-532.

Wuisan, F., Randa, F., \& Lukman, L. (2018). Pengaruh Struktur Kepemilikan Terhadap Kebijakan Dividen Perusahaan. Simak, 16(02), 119-141.

Yudiana, I., \& Yadnyana, I. K. (2016). Pengaruh Kepemilikan Manajerial, Leverage, Investment Opportunity Set Dan Profitabilitas Pada Kebijakan Dividen Perusahaan Manufaktur. E-Jurnal Akuntansi Universitas Udayana, 15(1), 112-141. 